\title{
Metallic mineralization associated with pillow basalts in the Yaeyama Central Graben, Southern Okinawa Trough, Japan
}

\author{
Makoto Watanabe ${ }^{1}$, Kenichi Hoshino ${ }^{1}$, Ryota Shiokawa ${ }^{1}$, Yuki Takaoka ${ }^{1}$, \\ Hideo Fukumoto ${ }^{1}$, Yasuhiro Shibata ${ }^{2}$, Ryuichi Shinjo ${ }^{3}$ and Tamotsu Oomori ${ }^{3}$
}

\begin{abstract}
Mineralogically investigated were massive sulfide samples of chimneys and mounds collected during the "SHINKAI 6500" dives (Dive 562 and Dive 567) from two basalt-hosted hydrothermal ore deposits, being at a short distance of about $1 \mathrm{~km}$, occurring in the eastern end of the Yaeyama Central Graben, the Southern Okinawa Trough. In both sample series (\#562- and \#567- series), ore minerals are dominated by low-iron sphalerite with small amounts of chalcopyrite and galena. Sphalerite in the \#567-series samples shows somewhat wide compositional variation, ranging from 0.4 to 3.8 mole $\% \mathrm{FeS}$, with the highest mode of about 1 to 2 mole $\%$ FeS. Significant amounts of pyrite and secondary marcasite are present in the \#562-series samples with subordinate bornite, while in the \#567-series samples, they are lacking, but instead tetrahedrite-tennantite series with atomic ratios of $\mathrm{Sb} /(\mathrm{Sb}+\mathrm{As})$ being 0.2 to 0.8 is abundant and contains $\mathrm{Ag}$ up to $0.7 \mathrm{wt} \%$ with mostly less than $0.5 \mathrm{wt} \%$. Neither pyrrhotite nor isocubanite is encountered in the two sample series. Microthermometries of two-phase (liquid + gas) fluid inclusions trapped in calcite (\#567-series) have revealed the following results: homogenization temperatures (not corrected for pressure) of 242 to $317{ }^{\circ} \mathrm{C}$ and salinities of 5.1 to $7.6 \mathrm{wt} . \% \mathrm{NaCl}$ equiv., being a little more saline than the seawater. The observed mineral assemblages and sphalerite compositions obtained for the Yaeyama Central Graben deposits lead us to indicate that the basalt-hosted mineralizations might have occurred under rather higher sulfidation state. From the mineral associations observed, it is also indicated that both hydrothermal deposits are characterized by a metal association of essentially $\mathrm{Zn}-\mathrm{Pb}-\mathrm{Cu}$. The mineral assemblages and ore textures observed are similar to those of the Kuroko deposits rather than the Besshi-type deposits, as well as their metal association $(\mathrm{Cu}-\mathrm{Pb}-\mathrm{Zn})$.
\end{abstract}

Keywords: Chimneys, mounds, massive sulfides, higher sulfidation state, basalt pillow lavas, Yaeyama Central Graben, Southern Okinawa Trough

\section{Introduction}

Since the discovery of a hydrothermal mound with $50{ }^{\circ} \mathrm{C}$ venting at the "Natsushima 84-1 Knoll" in 1986, extensive surveys of about 200 dives using the submersibles "SHINKAI 2000" and "SHINKAI 6500" have been carried out in the Okinawa Trough (e.g., Glasby and Notsu, 2003). In June 1988, as part of a joint German-Japanese project, the Central Okinawa Trough was surveyed by scientists on board of the R/V Sonne, with the resultant detection of an active hydrothermal field with extensive massive sulfide deposits in a caldera-like seafloor depression (Izena Cauldron), which was called the Jade hydrothermal field (JADE site). Due to their high contents of $\mathrm{Au}$ (up to $24 \mathrm{ppm}$ ) and $\mathrm{Ag}$ (up to $1.1 \mathrm{wt} . \%$ ) and to their close similarity to the Kuroko-type deposits, much attention has been paid to them as a probable modern analogue of the Kurokotype deposits (e.g., Halbach et al., 1989, 1993). Geochemistry of hydrothermal fluids has also been reported (Ishibashi et al., 1995).
Hydrothermal sites found in the Southern Okinawa Trough include those in the SPOT area (Southwestern Part of the Okinawa Trough, $122^{\circ}$ to $123.5^{\circ} \mathrm{E}$ ) (e.g., Sibuet et al., 1998; Shinjo et al., 1999) and those in the Yaeyama Central Graben, with their distribution shown in Figure 1. Hydrothermal deposits in the SPOT area are represented by those on the Dai-Yon Yonaguni Knoll site located at $24^{\circ} 50^{\prime} \mathrm{N}$ and $122^{\circ} 42^{\prime} \mathrm{E}$ at a water depth of about 1,400 m (e.g., Matsumoto et al., 2001) and by those on the Hatoma Knoll site located at $24^{\circ} 51^{\prime} \mathrm{N}$, $123^{\circ} 50^{\prime} \mathrm{E}$ at a water depth up to about $1,400 \mathrm{~m}$ (e.g., Watanabe, 2001). Both hydrothermal deposits are associated with two-pyroxene dacite (partly rhyolite) (K. Watanabe, personal comm.). Results of mineralogical studies of massive sulfide samples collected by the "SHINKAI 2000" dives from these hydrothermal deposits were reported by Okamoto et al. (2002).

During the "SHINKAI 6500" dive (Dive 562) in the eastern end of the Yaeyama Central Graben, also called the Irabu Knoll, 10 to $20 \mathrm{~km}$ wide and deepest in the

1 Graduate School of Science, Hiroshima University

2 Instrument Center for Chemical Analysis, Hiroshima University

3 Faculty of Science, University of the Ryukyus 


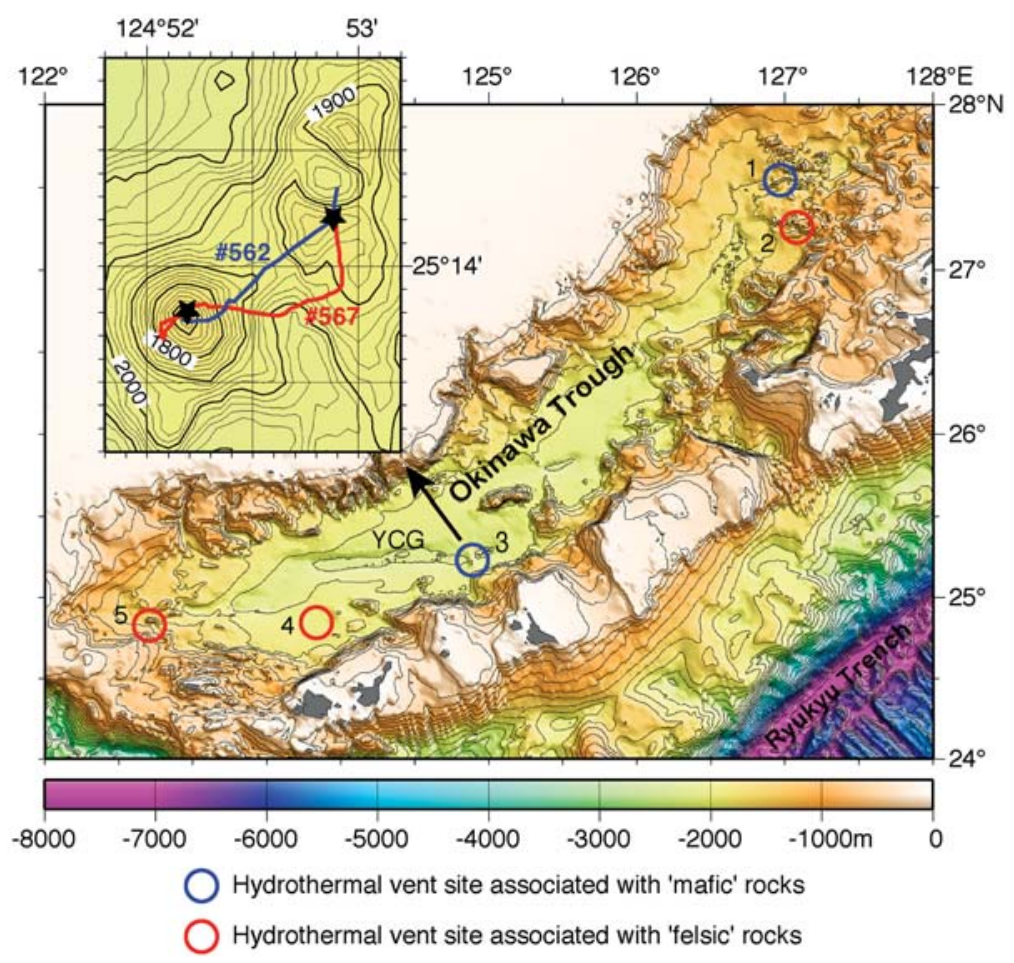

Figure 1: Bathymetric map of the Middle to Southern Okinawa Trough, showing location of hydrothermal vent sites. Depth data are based on J-EGG500 (JODCExpert Grid data for Geographic -500m) online data provided by the Japan Oceanographic Data Center (JODC: http://www.jodc.go.jp/service.htm). Contours are in $200 \mathrm{~m}$. YCG=Yaeyama Central Graben; 1 = CLAM site; 2 = JADE site; 3 = Irabu Knoll; 4 = Hatoma Knoll and $5=$ Dai-Yon Yonaguni Knoll. Inset shows tracks of SHINKAI-6500 dives (\#562 and \#567) with bathymetry obtained by multi-narrow beam survey during YK00-06 cruise (Matsumoto et al., 2001). Star indicates sampling point.

Okinawa Trough, a continuous exposure of fresh basalt pillow lavas was observed along a steep slope at a water depth of $1,920 \mathrm{~m}$ to $1,856 \mathrm{~m}$. The dive sites (No.3 in Figure 1) are unique in location, where magmatism within the Yaeyama Central Graben merges with the volcanic front. In this area, three volcanoes were recognized based on preliminary seabeam mapping (Matsumoto et al., 2001). The northern volcano has NSelongated feature with crater, about $300 \mathrm{~m}$ in diameter, that opens to the northwest. The southwestern volcano has cone shape. The southern volcano is EW-elongated. The former two volcanic edifices are shown in the inset of Figure 1, with dive tracks. Active hydrothermal venting and associated sulfide deposits were found near summit in each volcano (Matsumoto et al., 2001). In SHINKAI-6500 Dive 562, massive sulfide samples were taken in the northern volcano at $25^{\circ} 14.2121^{\prime} \mathrm{N}$, $124^{\circ} 52.8752^{\prime} \mathrm{E}$ (water depth $=1,850 \mathrm{~m}$ ). During the Dive 567 in the same area, sulfide samples were collected in the southwestern volcano at two sites $\left(25^{\circ} 13.7766^{\prime} \mathrm{N}, 124^{\circ} 52.1868^{\prime} \mathrm{E}, 1,657 \mathrm{~m} ; 25^{\circ} 13.7486^{\prime} \mathrm{N}\right.$, $\left.124^{\circ} 52.2076^{\prime} \mathrm{E}, 1,647 \mathrm{~m}\right)$. These hydrothermal deposits closely associated with basaltic pillow lavas might have distinct characters compared with those related to felsic magmas in other hydrothermal vent sites in the Okinawa Trough. However, mineralogical descriptions of the massive sulfide samples collected during these dives in the Yaeyama Central Graben area have not been published so far. In this paper, we report the results of mineralogical study on the massive sulfide samples collected during the "SHINKAI 6500" dives, Dive 562 and Dive 567.

\section{Sample descriptions}

\subsection{Brief descriptions of \#562 - series samples}

\#562-R5 and \#562-R6 samples They probably form part of mounds and were collected at one site $\left(25^{\circ} 14.212^{\prime} \mathrm{N}, 1^{\circ} 4^{\circ} 52.8752^{\prime} \mathrm{E} ; 1,850 \mathrm{~m}\right)$. Sulfide-rich samples are massive and compact, while gangue minerals-rich ones are somewhat porous. Representative photomicrographs of the massive sulfide samples are shown in Figure 2 (A to F). Under the microscope, ore minerals are dominated by low-iron sphalerite (being semi-transparent under transmitted light as shown by Figure $2 \mathrm{~F}$ ) 

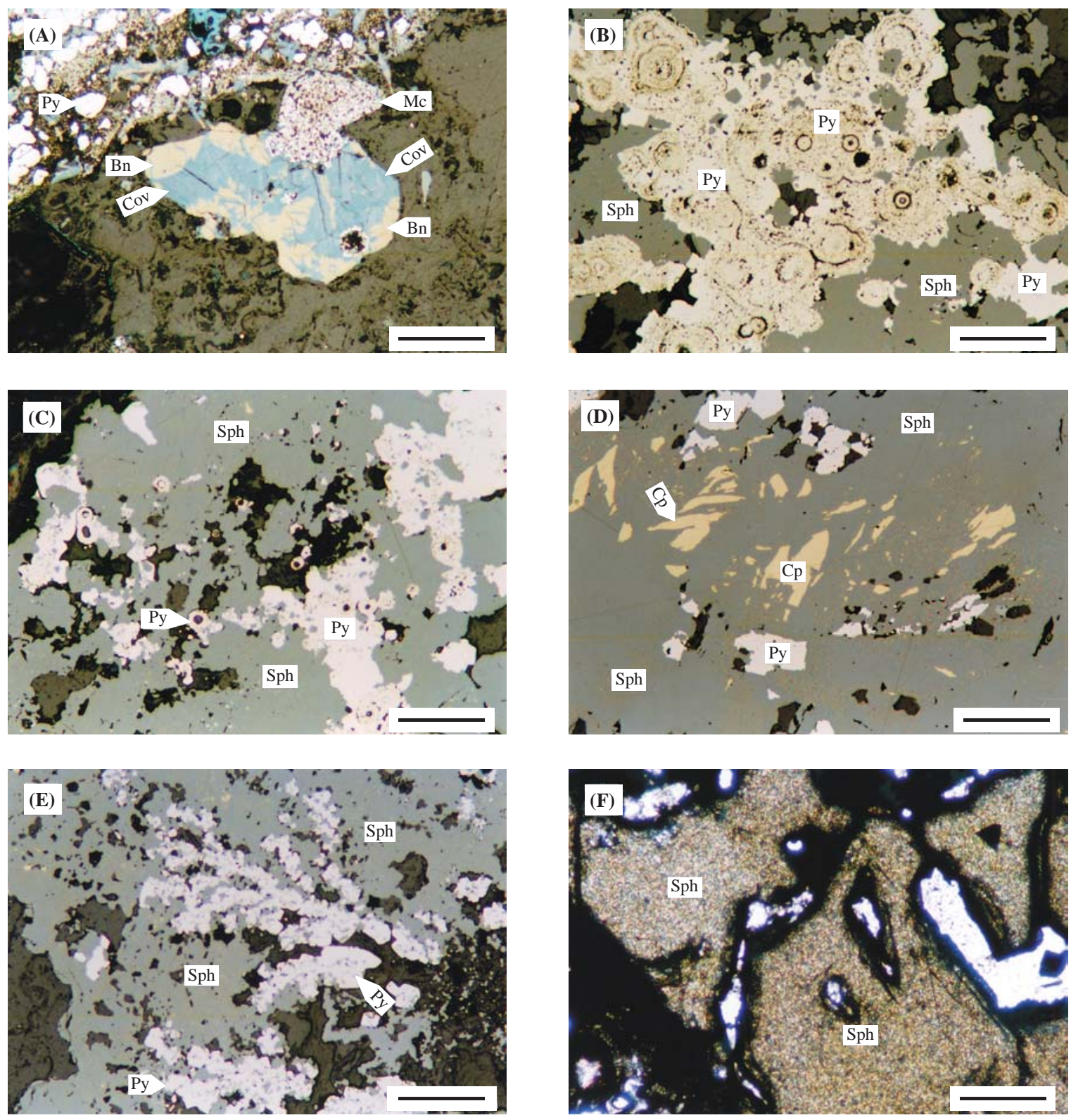

Figure 2: Representative photomicrographs of Dive 562-series samples (A-F)

(A) A large grain of bornite partially replaced by covelline in association with subhedral pyrite and marcasite. (B) Concentric colloform textures displayed by pyrite with their matrix being composed of sphalerite. (C) Concentric colloform and atoll textures displayed by pyrite with their matrix being composed of sphalerite. (D) Chalcopyrite "blades" and "chalcopyrite desease" in the sphalerite matrix. (E) Dendritic textures displayed by pyrite and sphalerite with their matrix being composed of sphalerite. (F) Semi-transparent sphalerite (so-called low-iron sphalerite) under transmitted light. Mineral abbreviations used are: $\mathrm{Cp}=$ chalcopyrite; $\mathrm{Bn}=$ bornite; $\mathrm{Py}=$ pyrite; $\mathrm{Mc}=$ marcasite; $\mathrm{Sph}=$ sphalerite; Gl=galena; TetTen=tetrahedrite-tennantite series; Cov=covelline. Scale bar indicates $10 \mu \mathrm{m}$ long.

and subordinate amounts of pyrite with small amounts of bornite, galena and chalcopyrite. Tetrahedrite-tennantite series is also present in very minor amounts. Neither pyrrhotite nor isocubanite is observed. Three types of textures are observed: as concentric colloforms mainly consisting of pyrite (Figure 2 B), as dendritic growth textures shown mainly by pyrite and sphalerite (Figure 2 E), and as aggregates of fragmentary pyrite crystals occurring in the interstices of large-grained sphalerite and barite. Secondary covelline (Figure 2 A) also occurs as replacement of bornite or chalcopyrite. Significant amounts of marcasite also occur as a secondary phase. Gangue minerals are composed mainly of barite with minor quartz (and/or amorphous silica), rhodochrosite and talc. Fluid inclusions available for microthermometry, regardless of whether included in sphalerite or in transparent minerals, are very few. 


\subsection{Brief descriptions of \#567 - series samples} \#567-R1 and \#567-R2 samples The samples, probably forming part of chimneys and mounds and closely associated with pillowed basalts, were collected at the following sites, respectively: $25^{\circ} 13.7766^{\prime} \mathrm{N}$ and $124^{\circ} 52.1868^{\prime} \mathrm{E}$ at a water depth of $1,657 \mathrm{~m}$; $25^{\circ} 13.7486^{\prime} \mathrm{N}$ and $124^{\circ} 52.2076^{\prime} \mathrm{E}$ at a water depth of $1,647 \mathrm{~m}$. Although they are usually massive and compact, well-banded structure composed of an arrangement of different minerals is seen in some of the mound samples. Some are characterized by the presence of "conduits" up to about $1.0 \mathrm{~cm}$ in diameter, suggesting their chimney origin. Representative photomicrographs of the massive sulfide samples are shown in Figure 3 (A to H).

Unlike the ore samples from the Dai-Yon Yonaguni Knoll site and the Hatoma Knoll site, there are no significant differences in mineralogy between the chimney and mound samples from the Yaeyama Central Graben, except one chimney composed exclusively of rhodochrosite, barite and talc with minor ore minerals, including low-iron sphalerite, galena and chalcopyrite. Minor stibioenargite was first found from the \#567-R2 sample throughout the Okinawa Trough. On the basis of total elements of 8 , its chemical formula is estimated as follows: $(\mathrm{Cu}+\mathrm{Ag}+\mathrm{Fe}+\mathrm{Zn})_{3}(\mathrm{Sb}+\mathrm{As})_{1} \mathrm{~S}_{4}$, in which proportions of $\mathrm{Sb}$ and As vary from 0.14 to 0.27 and 0.70 to 0.81 , respectively, with those of $\mathrm{Ag}+\mathrm{Fe}+\mathrm{Zn}$ being less than 0.02 . Ore minerals-rich samples are dominated by low-iron sphalerite with subordinate amounts of chalcopyrite, galena and tetrahedrite-tennantite series with some realgar. Ore minerals occur as aggregates of euhedral to subhedral crystals of sphalerite, galena. tetrahedrite-tennantite series and chalcopyrite (Figure 3 A, E) without dendritic textures and in places, form dendritic textures displayed by sphalerite, tetrahedrite-tennantite series and chalcopyrite (Figure 3 B, C, D, F, H). Grain size of crystals, especially of sphalerite and barite, irrespective of whether from the chimney or mound samples, show their outward decreasing crystal grainsize (Figure 4 A, B). Colloform textures are very rare, while dendritic textures are common. Usually, as shown in Figure 4 C, D), dendritic sphalerite intergrown with chalcopyrite and minor amounts of galena and tetrahedrite-tennantite series shows their outward growth of chimneys. Tetrahedrite-tennantite series with atomic ratios of $\mathrm{Sb} /(\mathrm{Sb}+\mathrm{As})$ being 0.2 to 0.8 contains $\mathrm{Ag}$ up to $0.7 \mathrm{wt} \%$ with mostly less than $0.5 \mathrm{wt} \%$. Sphalerite (\#567R1-1A, -3A; \#567R2-1A, -3C, -4C) shows somewhat wide compositional variation, ranging from 0.4 to 3.8 mole $\% \mathrm{FeS}$, with the highest mode of about 1 to 2 mole $\% \mathrm{FeS}$. Although usually well-crystallized chalcopyrite is concentrated along conduits within chimneys as reported from massive sulfide deposits occurring in mid-oceanic environments, including the Rainbow hydrothermal field, Mid-Atlantic Ridge (e.g., Lee et al., 2002), tetrahedrite-tennnantite series closely intergrown with sphalerite is growing along conduits of the chimneys in the \#567-series samples (Figure $3 \mathrm{H}$ ). None of pyrite, pyrrhotite, marcasite and isocubanite is recognized. Gangue minerals-rich samples are composed mainly of barite and amorphous silica with lesser amounts of anhydrite, calcite, rhodochrosite and talc.

Microthermometry of two-phase (liquid + gas) inclusions trapped in calcite taken from the sulfide mound sample (\#567R2-4C) has yielded the following results: homogenization temperature (not corrected for pressure) of 242 to $317{ }^{\circ} \mathrm{C}$ and salinity of 5.1 to $7.6 \mathrm{wt} . \% \mathrm{NaCl}$ equiv. Salinities measured are plotted against homogenization temperatures in Figure 5. The estimated salinity of the hydrothermal fluid is somewhat higher than that of the seawater.

\section{Discussion}

Chimney and mound samples closely associated with basalt pillow lavas from the eastern end of the Yaeyama Central Graben, Southern Okinawa Trough, were briefly described. It is interesting to notice the fact that, though both deposits being hosted by basalt pillow lavas, there are mineralogical differences and similarities between the \#562 site and the \#567 site located about $1 \mathrm{~km}$ southwest of the former. Fe-S minerals, including pyrite, pyrrhotite and marcasite are absent in the \#567series samples. In the \#562-series samples, tetrahedritetennantite series is very rare, but instead bornite is common. Galena, though varying in amounts, is always observed in both types of samples, while none of pyrrhotite and isocubanie is encountered in the two sample series. On the other hand, massive sulfide ore samples in both sites are characteristically dominated by low-iron sphalerite. The observed mineral assemblages and sphalerite compositions suggest that the basalt-hosted mineralizations might have taken place under rather higher sulfidation state. From the mineral associations observed, it is also indicated that both hydrothermal deposits are characterized by a metal association of essentially $\mathrm{Zn}-\mathrm{Pb}-\mathrm{Cu}$.

It is to be noted that the mineral assemblages and ore textures observed are very similar to those of felsic volcanics-hosted Kuroko deposits in the Hokuroku district, Akita Prefecture, northeastern Japan. For the mineral assemblages and ore textures observed in the Kuroko deposits, see, for instance, Sato (1974), Watanabe (1974) and Eldridge et al. (1983). Thus, they are different from those of the basalt-hosted Besshi-type deposits 

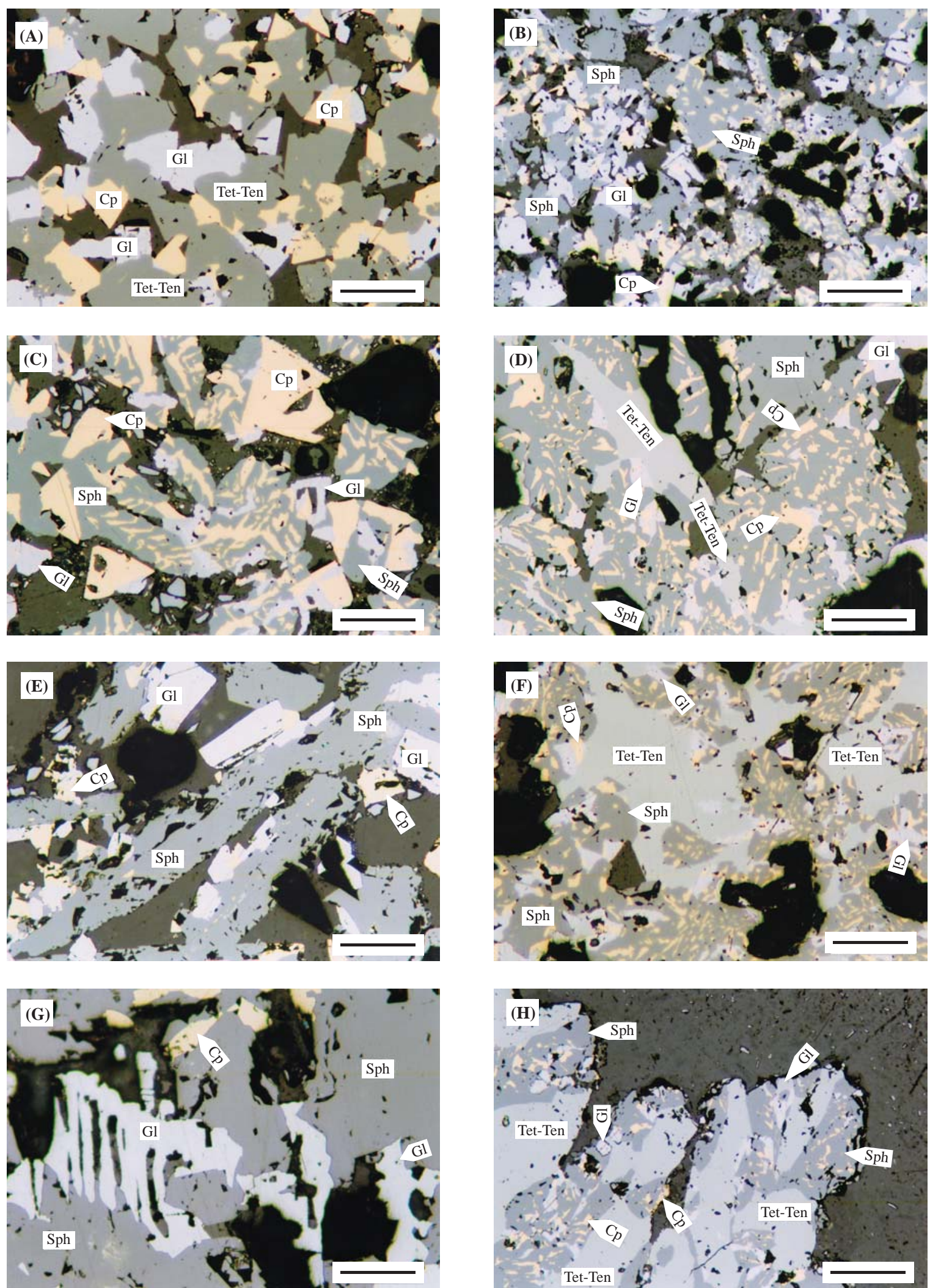

Figure 3: Representative photomicrographs of Dive 567-series samples (A-H)

(A) Aggregates of euhedral to subhedral and equigranular crystals, including tetrahedrite-tennantite series, chalcopyrite and galena. (B) Sphalerite intergrown with galena and chalcopyrite. (C) Dendritic intergrowth of sphalerite, chalcopyrite and galena. (D) Sphalerite intergrown with tetrahedrite-tennantite series, galena and chalcopyrite. (E) Rod-like sphalerite intergrown with euhedral galena and minor chalcopyrite. (F) Tetrahedite-tennantite series closely associated with chalcopyrite blebs-rich sphalerite and galena. (G) Skeltal growth of galena intergrown with sphalerite and minor chalcopyrite. (H) Dendritic intergrowth of tetrahedite-tennantite series, sphalerite and minor chalcopyrite. They are growing towards a conduit within a chimney. Mineral abbreviations used are the same as those in Figure 2. Scale bar indicates $10 \mu \mathrm{m}$ long. 

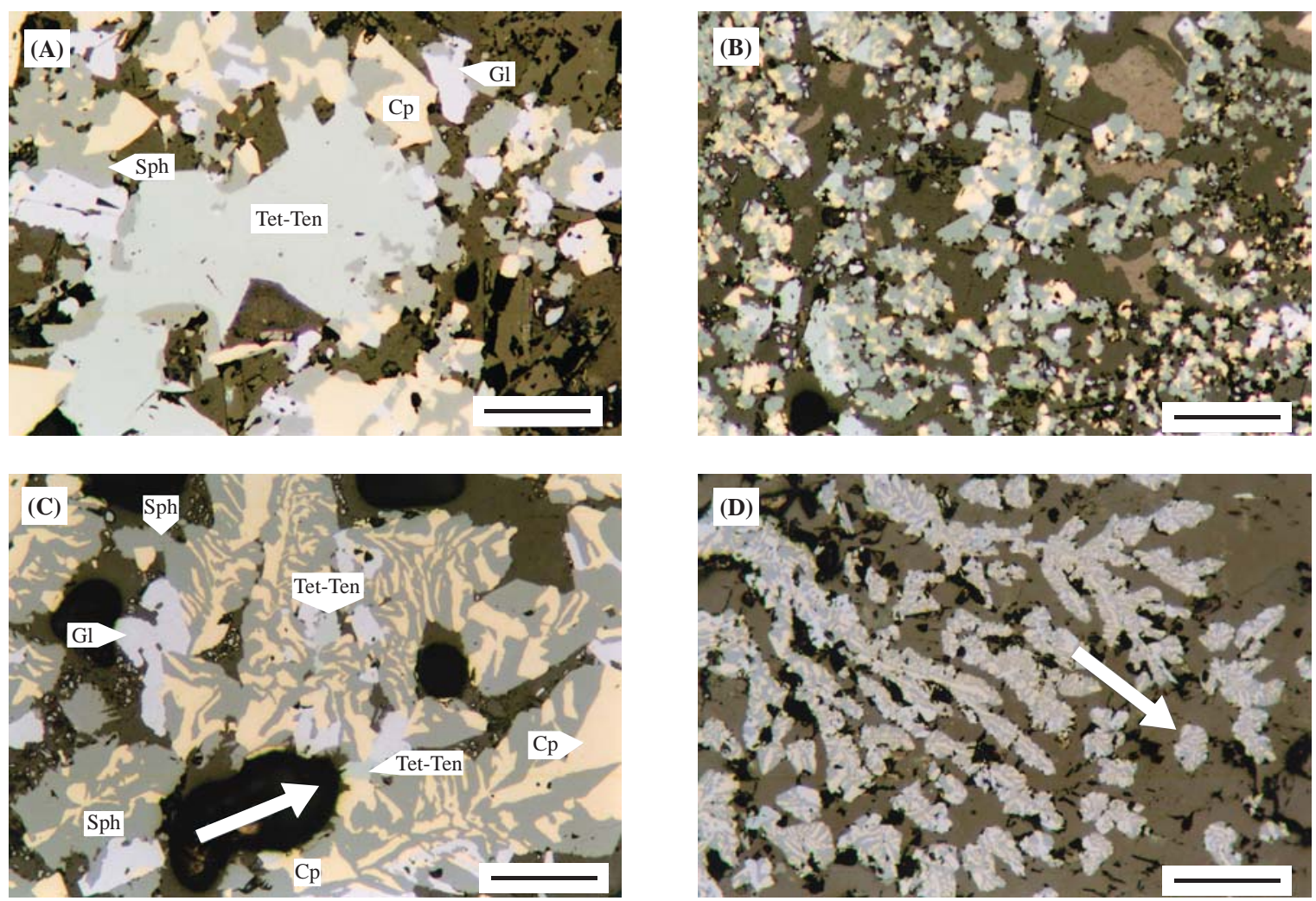

Figure 4: Photomicrographs of Dive-567 series samples (A to D). (A) (inside) and (B) (outside): showing outward decreasing grainsize of crystals within a chimney sample. (C) (inside) and (D) (outside): showing outward growth of dendritic intergrowth with chalcopyrite and lesser amounts of galena and tetrahedite-tennantite series as displayed by a white arrow. Mineral abbreviations used are the same as those in Fig. 2. Scale bar indicates $10 \mu \mathrm{m}$ long.

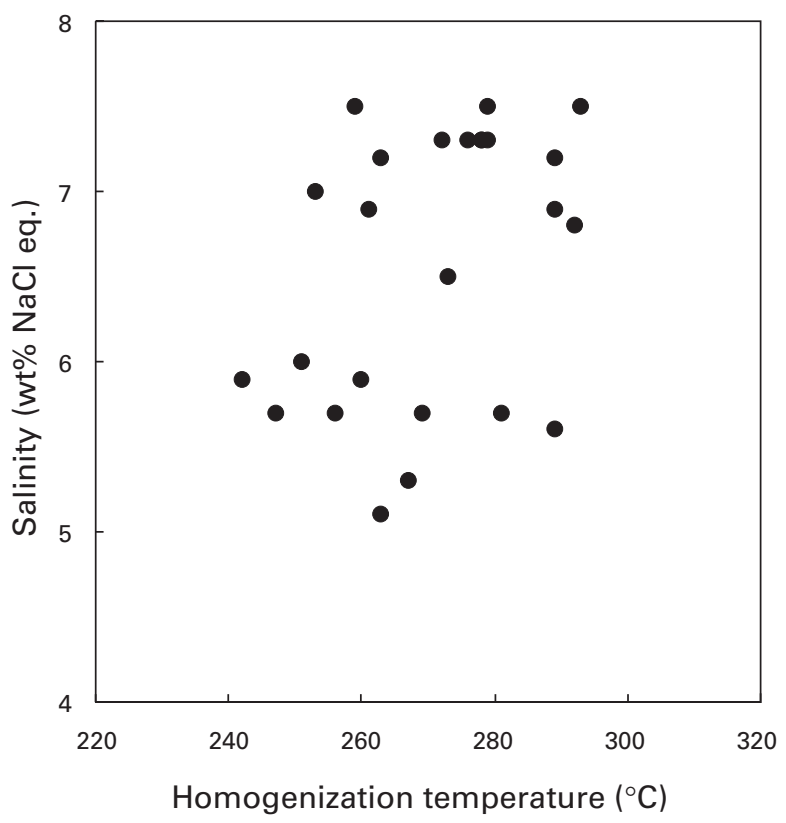

Figure 5: Salinities (in wt.\% $\mathrm{NaCl}$ equiv.) of two-phase (liquid + gas) fluid inclusions trapped in calcite plotted against homogenization temperatures (not corrected for pressure) in that in particulr, galena is absent or present in only minor amounts and the Besshi-type ores are essentially $\mathrm{Cu}( \pm \mathrm{Zn}$ )-type (e.g., Kase and Yamamoto, 1988; Watanabe et al., 1993).

However, stringer zones, corresponding to underlying siliceous ore zone ("Keiko zone") in the Kuroko deposits, are apparently lacking in these basalt-hosted massive sulfide deposits. As is inferred from massive sulfide deposits occurring in other back-arc basins, including the Lau Basin (e.g., Fouquet et al., 1993) and also in mid-oceanic ridge environments, including the TAG hydrothermal field, Mid-Atlantic Ridge (e.g., Rona et al., 1993), it is likely that such zone might exist beneath the mounds as networks or veinlets.

Nakashima et al. (1995) reported the following microthermometric results obtained for two-phase fluid inclusions trapped in coarse-grained calcite in the Pyramid chimney associated with basalt pillow lavas at the CLAM site $\left(27^{\circ} 33^{\prime} \mathrm{N}, 126^{\circ} 58^{\prime} \mathrm{E}\right.$, water depth of $1.392 \mathrm{~m}$ ), Iheya Ridge, Central Okinawa Trough: homogenization temperatures ranging from 204 to $338^{\circ} \mathrm{C}$ and salinities ranging from 3.37 to 5.70 wt. $\% \mathrm{NaCl}$ equiv. The homogenization temperatures obtained by the present study are in good accordance with their results, while the estimated salinities of the 
hydrothermal fluid are a little more saline than those. It is interesting to note that both salinity data are somewhat higher than those of the seawater.

Comparison between the basalt-hosted sulfide deposits described here and other sulfide deposits occurring in the Okinawa Trough, regardless of whether hosted by mafic or felsic volcanics, will be made somewhere, from the viewpoint of VMS (volcanogenic massive sulfide deposits) genesis (Watanabe et al., in prep.).

\section{Summary}

We have mineralogically investigated massive sulfide samples of chimneys and mounds collected during the "SHINKAI 6500" dives (Dive 562 and Dive 567) from two basalt-hosted small-scale hydrothermal ore deposits, occurring in the eastern end of the Yaeyama Central Graben, the Southern Okinawa Trough. In both sample series (\#562- and \#567- series), ore minerals are dominated by low-iron sphalerite with small amounts of chalcopyrite and galena. Significant amounts of pyrite and secondary marcasite are present in the \#562-series samples with subordinate bornite, while in the \#567series samples, they are lacking, but instead tetrahedritetennantite series is abundant. Neither pyrrhotite nor isocubanite is encountered in the two sample series. Microthermometries of two-phase fluid inclusions trapped in calcite (\#567-series) have revealed the following results: homogenization temperatures (not corrected for pressure) of 242 to $317{ }^{\circ} \mathrm{C}$ and salinities of 5.1 to 7.6 wt. $\% \mathrm{NaCl}$ equiv., being a little more saline than the seawater. The basalt-hosted mineralizations are likely to have occurred under rather higher sulfidation state. Both hydrothermal deposits are characterized by a metal association of essentially $\mathrm{Zn}-\mathrm{Pb}-\mathrm{Cu}$. The mineral assemblages and ore textures observed are similar to those of the Kuroko deposits rather than the Besshi-type deposits, as well as their metal association $(\mathrm{Cu}-\mathrm{Pb}-\mathrm{Zn})$.

\section{Acknowledgements}

We are deeply grateful to captain and crews of R/V Yokosuka and operation team of the "SHINKAI 6500" of JAMSTEC for their kind support during the cruises. The GMT software package was used to make some of the figures (Wessel and Smith, 1991).

\section{References}

1) Eldridge, C. S., Barton, P. B. Jr., and Ohmoto, H., Mineral textures and their bearing on formation of the Kuroko orebodies, Econ. Geol. Monograph, 5, 241-281 (1983).

2) Fouquet, Y., Von Stackelberg, U., Charlou, J. L., Erzinger, J., Hertzig, P. M., Mühe, R. and Wiedicke M., Metallogenesis in back-arc environments: The Lau Basin example, Econ. Geol., 88, 2154-2181 (1993).
3) Glasby, G. P. and Notsu, K., Submarine hydrothermal mineralization in the Okinawa Trough, SW of Japan: an overview, Ore Geology Review, 23, 299-339 (2003).

4) Halbach, P., Nakamura, K., Wahsner, M., Lange, J., Sakai, H., Käselitz, L., Hansen, R -D., Yamano, M., Post, J., Prause, B., Seifert, R., Michaelis, W., Teichmann, F., Kinoshita, M., Märten, A., Ishibashi, J -I., Czerwinski, S. and Blum, N., Probable modern analogue of kuroko-type massive sulphide deposits in the Okinawa trough back-arc basin, Nature, 338, 496-4991993 (1989).

5) Halbach, P., Pracejus, B., and Märten, A., Geology and mineralogy of massive sulfide ores from the Central Okinawa Trough, Econ. Geol., 88, 2210-2225 (1993).

6) Ishibashi, J., Sano, Y., Wakita, H., Gamo, T., Tsutsumi. M., and Sakai, H., Helium and carbon geochemistry of hydrothermal fluids from the Mid-Okinawa Trough Back Arc Basin, southwest of Japan, Chem. Geol., 123, 1-15 (1995).

7) Kase, K. and Yamamoto, M., Minerals and geochemical characteristics of ores from the Besshi-type deposits in the Sambagawa Belt, Japan, Mining Geology, 38, 203-214 (1988).

8) Lee, S. Y., Watanabe, M., Hoshino, K., Oomori, T., Fujioka, K., and Rona, P., First report of linnaeite $\left(\mathrm{Co}_{3} \mathrm{~S}_{4}\right)$ and millerite (NiS) from active submarine hydro- thermal deposits: Rainbow hydrothermal field, Mid-Atlantic Ridge at $36^{\circ} 14^{\prime} \mathrm{N}$, Neues Jahrbuch für Mineralogie Mh., Jg.2002, 1-21 (2002).

9) Matsumoto, T., Kinoshita, M., Nakamura, M., Sibuet, J -C., Lee, C -S., Hsu, S-K., Oomori, T., Shinjo, R., Hashimoto, Y., Hosoya, S., Imamura, M., Ito, M., Tukuda, K., Yagi, H., Tatekawa, K., Kagaya, I., Hokakubo, S., Okada, T., and Kimura, M., Volcanic and Hydrothermal activities and possible "segmentation" of the axial rifting in the westernmost part of the Okinawa Trough - preliminary results from the YOKOSUKA/SHINKAI 6500 Lequios Cruise, JAMSTEC Journal of Deep-Sea Research, 19, 95-107 (2001). (in Japanese with English abstract).

10) Nakashima, K., Sakai, H., Yoshida, H., Chiba, H., Tanaka, Y., Gamo, T., Ishibashi, J., and Tsunogai, U., Hydothermal mineralization in the Mid-Okinawa Trough. In: Biogeochemical Processes and Ocean Flux in the Western Pacific, Eds. H. Sakai and Y. Nozaki, 487-508 (1995). Terra Sci. Pub. Comp. (TERAPUB), Tokyo.

11) Okamoto, K., Ishibashi, J -I., Motomura, Y., Yamanaka, T., and Fujikura, K., Mineralogical studies of hydrothermal deposits collected from the Dai-Yon Yonaguni Knoll and the Hatoma Knoll in the Okinawa Trough, JAMSTEC Journal of Deep-Sea Research, 21, 75-81 (2002). (in Japanese with English abstract).

12) Rona, P. A., Hannington, M. D., Raman, C. V., 
Thompson, G., Tivey, M. K., Humphris, S. E., Lalou, C., and Petersen, S., Active and relict sea-floor hydro- thermal mineralization at the TAG hydrothermal field, MidAtlantic Ridge, Econ. Geol., 88, 1989-2017 (1993).

13) Sato, J., Ores and ore minerals from the Shakanai mine, Akita Prefecture, Japan. In: Geology of Kuroko Deposits. Eds. S. Ishihara, Mining Geology Special Issue, 6, 323335 (1974).

14) Shinjo, R., Chung, S -L., Kato, and Y., Kimura, M., Geochemical and Sr-Nd isotopic characteristics of volcanic rocks from the Okinawa trough and Ryukyu Arc: implications for the evolution of a young intracontinental back-arc basin, J. Geophys. Res., 104, 10591-10608 (1999).

15) Sibuet, J -C., Deffontaines, B., Hsu, S -K., Thareau, N., Le Formal J -P, Liu C -S., and ACT Party, Okinawa trough backarc basin: early tectonic and magmatic evolution, J. Geophys. Res., 103, 30245-30267 (1998).
16) Watanabe, K., Mapping of hydrothermal activity area on the Hatoma Knoll in the southern Okinawa Trough, JAMSTEC Journal of Deep-Sea Research, 19, 87-94 (2001). (in Japanese with English abstract).

17) Watanabe, M., On the textures of ores from the Daikoku ore deposit, Ainai mine, Akita Prefecture, northeast Japan, and their implications in the ore genesis. In: Geology of Kuroko Deposits, Eds. S. Ishihara, Mining Geology Special Issue, 6, 337-348 (1974).

18) Watanabe, M., Hoshino, K., Osaki, T., Yukawa, M., Sugiyama, M., Nishido, H. and Kagami, H., Mineralogy and geochemistry of Besshi-type deposits and related green rocks in the Sanbagawa belt, Japan, Resource Geology Special Issue, No.17, 213-228 (1993).

19) Wessel, P. and Smith, W. M. F., Free software helps map and display data, Eos Trans. AGU, 72, 441-446 (1991).

(Received October 13, 2005) 